\title{
TU/e emonowne

\section{Surface fluorination of ALD TiO2 electron transport layer for efficient planar Perovskite solar cells}

\section{Citation for published version (APA):}

Zardetto, V., Di Giacomo, F., Lifka, H., Verheijen, M. A., Weijtens, C. H. L., Black, L. E., Veenstra, S., Kessels, W. M. M., Andriessen, R., \& Creatore, M. (2018). Surface fluorination of ALD TiO electron transport layer for efficient planar Perovskite solar cells. Advanced Materials Interfaces, 5(9), [1701456]. https://doi.org/10.1002/admi.201701456

\section{Document license: \\ TAVERNE}

DOI:

10.1002/admi.201701456

Document status and date:

Published: 09/05/2018

\section{Document Version:}

Publisher's PDF, also known as Version of Record (includes final page, issue and volume numbers)

\section{Please check the document version of this publication:}

- A submitted manuscript is the version of the article upon submission and before peer-review. There can be important differences between the submitted version and the official published version of record. People interested in the research are advised to contact the author for the final version of the publication, or visit the $\mathrm{DOI}$ to the publisher's website.

- The final author version and the galley proof are versions of the publication after peer review.

- The final published version features the final layout of the paper including the volume, issue and page numbers.

Link to publication

\section{General rights}

Copyright and moral rights for the publications made accessible in the public portal are retained by the authors and/or other copyright owners and it is a condition of accessing publications that users recognise and abide by the legal requirements associated with these rights.

- Users may download and print one copy of any publication from the public portal for the purpose of private study or research.

- You may not further distribute the material or use it for any profit-making activity or commercial gain

- You may freely distribute the URL identifying the publication in the public portal.

If the publication is distributed under the terms of Article 25fa of the Dutch Copyright Act, indicated by the "Taverne" license above, please follow below link for the End User Agreement:

www.tue.nl/taverne

Take down policy

If you believe that this document breaches copyright please contact us at:

openaccess@tue.nl

providing details and we will investigate your claim. 


\title{
Surface Fluorination of ALD $\mathrm{TiO}_{2}$ Electron Transport Layer for Efficient Planar Perovskite Solar Cells
}

\author{
Valerio Zardetto,* Francesco di Giacomo, Herbert Lifka, Marcel A. Verheijen, \\ Christ H. L. Weijtens, Lachlan E. Black, Sjoerd Veenstra, Wilhelmus M. M. Kessels, \\ Ronn Andriessen, and Mariadriana Creatore
}

Perovskite solar cells (PSCs) are emerging among the photovoltaic (PV) technologies due to their high power conversion efficiency (PCE) in combination with potentially low cost manufacturing processing. In this contribution, the fabrication of efficient planar $n$-i-p PSCs by the modification of the electron transport layer (ETL) adopted as n-type contact is demonstrated. Specifically, a fluorine-based plasma treatment prior to perovskite deposition leads to surface fluorination of the $\mathrm{TiO}_{2} \mathrm{ETL}$. The presence of fluorine on the $\mathrm{TiO}_{2}$ surface drastically improves the adhesion between the ALD layer and the methylammonium lead iodide perovskite film, and leads to a more favourable energy band alignment, accompanied by a faster electron carrier extraction at the interface. As consequence of surface fluorination, we observe a significant reduction in the current density-voltage curve hysteresis with respect to the ALD based reference sample, as well as a remarkable improvement in power conversion efficiency from $4 \%$ up to a stable $14.8 \%$.

development of several device architectures. So far, the most efficient solar cells have been developed in a so-defined mesoscopic configuration, with PCEs above $21 \% .{ }^{[1,4]}$ In this configuration, the perovskite absorber is grown onto a high temperature sintered $\left(500{ }^{\circ} \mathrm{C}\right)$ mesoporous $\mathrm{TiO}_{2}$ scaffold, which acts as electron transport layer (ETL) in combination with a compact $\mathrm{TiO}_{2}$ layer underneath, while a Spiro-OMeTAD or PTAA layer is adopted as hole transport layer (HTL). Alternative to that, the "planar" PSC configurations consist of the perovskite absorber placed in between the ETL and the HTL, i.e., without the presence of a scaffold. In the n-i-p stack (ETL/perovskite/HTL), the ETL is generally a compact n-type metal oxide layer, such as $\mathrm{TiO}_{2}$ or, recently, $\mathrm{SnO}_{2} \cdot{ }^{[5,6]}$ In case of low-temperature deposited ETL, typi-

Organo-lead halide perovskite solar cells (PSCs) emerged in the last years as an extremely interesting photovoltaic (PV) technology due to the high power conversion efficiency (PCE of 22.1\%), ${ }^{[1]}$ low-temperature processing $\left(<150{ }^{\circ} \mathrm{C}\right)$, and low-cost deposition techniques. ${ }^{[2]}$ Furthermore, the tunable band gap of this class of materials enables the use of PSCs as top cells in tandem architecture with other industrial PV devices, such as crystalline silicon (c-Si) and copper-indium-gallium-selenide (CIGS) bottom cells. ${ }^{[3]}$ The understanding of the optoelectronic behavior of the organo-lead halide absorbers allowed the

Dr. V. Zardetto, Dr. F. di Giacomo, H. Lifka, Dr. R. Andriessen TNO/Host/Solliance

High Tech Campus 21, 5656 AE Eindhoven, The Netherlands E-mail: valerio.zardetto@tno.nl

Dr. V. Zardetto, Dr. C. H. L. Weijtens, Dr. L. E. Black,

Prof. W. M. M. Kessels, Prof. M. Creatore

Department of Applied Physics

Eindhoven University of Technology

P.O. Box 513, 5600 MB, Eindhoven, The Netherlands

Dr. M. A. Verheijen

Philips Innovation Labs

High Tech Campus 11, 5656 AE, Eindhoven, The Netherlands

Dr. S. Veenstra

ECN/Solliance

High Tech Campus 21, 5656 AE, Eindhoven, The Netherlands

DOI: 10.1002/admi.201701456 cally between room temperature and $150{ }^{\circ} \mathrm{C}$, the lack of a hightemperature step enables exploiting flexible plastic foils which would allow potential low cost roll to roll (R2R) manufacturing processes. ${ }^{[7]}$ The two above-mentioned ETL films can be deposited by different low-temperature deposition methods. While solution processing is the most common approach especially for lab scale devices, ${ }^{[5,8]}$ alternative methods, such as sputtering ${ }^{[9]}$ and atomic layer deposition (ALD) ${ }^{[6,10-15]}$ have been also recently explored. ALD is a powerful technique, industrially adopted in silicon solar cells and widely explored in CIGS solar cells, ${ }^{[16]}$ due to the atomic-scale control of the deposited materials, the highly conformality, and uniformity over large area, as well as on complex structures. ${ }^{[17,18]}$ Furthermore, the spatial ALD approach can combine the benefit of the conventional ALD with the industrial requirement of fast processing over large area, both for sheet to sheet and R2R manufacturing. ${ }^{[19]}$ In the last years, the ALD technique gained momentum also in the field of PSCs. ${ }^{[20]}$ Several groups demonstrated high PCEs using ALD $\mathrm{TiO}_{2}$ in combination with a mesoporous $\mathrm{TiO}_{2}$ scaffold, both for glass-[10,21,22] and plastic-based PSCs. ${ }^{[12,15]}$ However, contrasting results are observed when ALD $\mathrm{TiO}_{2}$ films were adopted as ETLs in n-i-p planar configuration. Kim et al. ${ }^{[14]}$ reported a PCE above $12 \%$, claiming that the lower defect density at the $\mathrm{ALD} \mathrm{TiO}_{2}$ surface, and the lower amount of bulk impurities allowed high performance with respect to the device with solution-processed $\mathrm{TiO}_{2}$ (4.3\%). In our previous investigations on indium tin oxide coated polyethylene terephthalate (ITO/PET), ${ }^{[12,23]}$ we reported 



Figure 1. a) $J-V$ curves for the perovskite solar cells having the ALD $\mathrm{TiO}_{2}$ as $\mathrm{ETL}$ (solid black line) and $\mathrm{CF}_{4}$ plasma treated ALD (dash red line); b) maximum power point tracking (MPPT) for the two devices.

efficiencies below $3 \%$, and similar results were obtained in the work of Correa Banea et al. ${ }^{[6]}$ In the latter, it was pointed out that the conduction band (CB) misalignment between the $\mathrm{TiO}_{2}$ and the perovskite was the main limiting factor, suggesting ALD $\mathrm{SnO}_{2}$ as valid alternative due to its deeper CB. Next to the choice of another metal oxide to control the ETL/perovskite interface, recently Tan et al. ${ }^{[5]}$ proposed a strategy to improve the performance of a planar PSC based on a solution-processed $\mathrm{TiO}_{2}$ ETL: by chlorination of $\mathrm{TiO}_{2}$ nanoparticles, the PSC performance was significantly enhanced, thanks to a stronger chemical binding between the Cl-terminated $\mathrm{TiO}_{2}$ and the perovskite materials, which mitigated the interfacial recombination. Therefore, the control of the $\mathrm{TiO}_{2}$ /perovskite interface is found to be crucial for efficient PSC devices. Recently, several studies look at the use of fluorine-based chemicals to achieve contact passivation and increase the overall PV performance. Fluorinated salt has been added in the perovskite formulation, ${ }^{[24]}$ as well as fluorine functional groups have been added to a reduced graphene oxide, ${ }^{[25]}$ and fluorinated compounds have been adopted as interfacial materials in p-i-n configuration. ${ }^{[26]}$

In this communication, we propose for the first time a posttreatment of $\mathrm{CF}_{4}$-fed plasma to modify the chemical surface composition of low-temperature deposited ALD $\mathrm{TiO}_{2}$ for n-i-p planar PSC devices. We found that this process leads to a fluorine-rich surface, which drastically improves the adhesion/ bonding with the perovskite layer when compared to the case of the pristine $\mathrm{TiO}_{2}$. The $\mathrm{CF}_{4}$ plasma treated device achieves a stable PCE of $14.8 \%$, which is, to our knowledge, the highest performance for a planar PSC based on a low-temperature ALD $\mathrm{TiO}_{2}$ ETL. This value is higher than the $4 \%$ obtained with the pristine ALD $\mathrm{TiO}_{2}$, and furthermore, the PCE remains stable also during continuous light exposure of $15 \mathrm{~h}$.

Figure 1 shows the $J-V$ characteristics and the maximum power point tracking (MPPT) of two different ALD TiO ${ }_{2}$ based PSCs, with and without $\mathrm{CF}_{4}$ plasma treatment. The reference device (i.e., without any $\mathrm{CF}_{4}$ plasma) exhibits low performance, with a large hysteresis in the $J-V$ curves (Figure 1a) and an MPPT value which decreases below $4 \%$ after the $300 \mathrm{~s}$. Despite the use of a different titanium precursor for the ALD process (see the Experimental Section) with respect to our previous investigations, ${ }^{[12,23]}$ and the work of Correa Baena et al. ${ }^{[6]}$ the achieved results are similar, i.e., the $\mathrm{TiO}_{2}$ layer does not serve as efficient ETL. The effect of only $2 \mathrm{~min}$ exposure to $\mathrm{CF}_{4}$-fed plasma prior to deposition of the perovskite solution drastically reduces the hysteresis in the $J-V$ curves (Figure 1a) and boosts the PV parameters (Table S1, Supporting Information). In addition to that, the MPPT value remains very stable at $14.8 \%$ over $300 \mathrm{~s}$ and at $14.6 \%$ after $15 \mathrm{~h}$ of continuous illumination (Figure S1, Supporting Information). The improvement in PCEs and other PV parameters is observed when the $\mathrm{CF}_{4}$ plasma is ignited for 1 and $2 \mathrm{~min}$, whereas a process of $5 \mathrm{~min}$ increases the standard deviation of the PV parameters (see Figures S2 and S3, Supporting Information). In the latter case, the $\mathrm{CF}_{4}$ plasma induces discoloration in the ALD $\mathrm{TiO}_{2}$ layers, presumably due to etching, ${ }^{[27]}$ and consequently, leads to PSC devices with an inhomogeneous ETL.

As mentioned above, the control on the interface between the ALD $\mathrm{TiO}_{2}$ layer and the perovskite is crucial to obtain highefficient PSCs. When the bulk crystallinity of the perovskite films on top of the ALD $\mathrm{TiO}_{2}$ layers with and without the $\mathrm{CF}_{4}$ treatment is evaluated by means of X-ray diffraction (XRD), the two spectra are identical (Figure S4, Supporting Information), pointing out that the bulk quality of the perovskite is not affected by the plasma treatment.

We therefore investigate the effect of the $\mathrm{CF}_{4}$ treatment on the ALD layer by X-ray photoelectron spectroscopy (XPS). The measurement of the $\mathrm{TiO}_{2}$ surface after the $\mathrm{CF}_{4}$ plasma reveals a high intensity of the $\mathrm{F} 1 \mathrm{~s}$ signal at binding energy (BE) $684.7 \mathrm{eV}$ (see Figure 2a), which is assigned to the Ti-F bond, ${ }^{[28,29]}$ without any contribution at higher BE $(688-689 \mathrm{eV})$, therefore excluding the presence of fluorine-carbon bonds. No fluorine is detected in case of the reference ALD $\mathrm{TiO}_{2}$ layer (without $\mathrm{CF}_{4}$ treatment) as reported in Figure 2a. Large differences are observed also in the Ti2p XPS signal. After the $\mathrm{CF}_{4}$ plasma, the Ti2p3/2 signal consists of two contributions: one at $\mathrm{BE}$ of $458.3 \mathrm{eV}$, typical of Ti2p3/2 peak, and associated to $\mathrm{Ti}-\mathrm{O}$ bond, ${ }^{[30]}$ and one at $459.4 \mathrm{eV}$, assigned to the combination of $\mathrm{Ti}-\mathrm{F}$ bonds and fluorinated $\mathrm{TiO}_{2}$ environments. ${ }^{[28]}$ A small additional peak centered at $456.5 \mathrm{eV}$ is also observed and assigned to titanium at lower oxidation states, i.e., related due to oxygen vacancies. ${ }^{[29]}$ In case of the reference ALD $\mathrm{TiO}_{2}$, the main contribution arises from the Ti-O bonds (Figure 2d), with the additional small shoulder at lower BE $(456.5 \mathrm{eV})$. The fluorine detected on the surface on the $\mathrm{CF}_{4}$ plasma treated ALD $\mathrm{TiO}_{2}$ replaces a third of the oxygen atoms with respect to the 

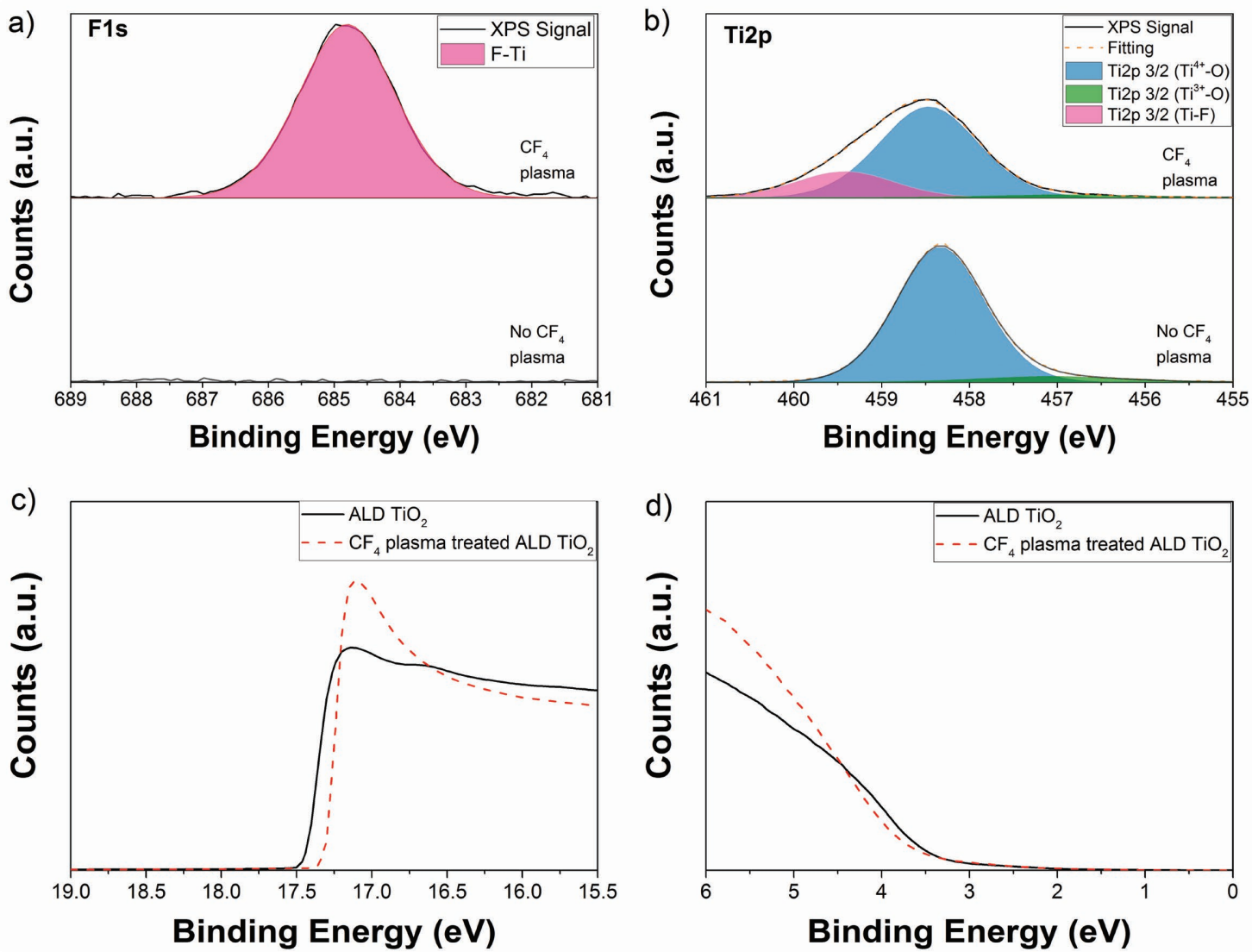

Figure 2. XPS and UPS analysis for the ALD TiO 2 layers with and without $\mathrm{CF}_{4}$ plasma treatment: a) F 1s signal, b) Ti $2 p$, c,d) the cut-off (secondary edge emission) and valence band spectra.

reference $\mathrm{TiO}_{2}$ layer (see Table $\mathrm{S} 2$, Supporting Information). This fluorine content is present only at the surface, since no signal is detected after a mild sputtering procedure, i.e., the chemical composition of the plasma treated $\mathrm{TiO}_{2}$ is identical to the one of the reference $\mathrm{TiO}_{2}$ layer (see Table S2, Supporting Information). The modification of the surface has an effect also on the energy levels of the ALD layers. From ultraviolet photoelectron spectroscopy (UPS) measurements we calculate that the work function (WF) and the ionization potential (IP) of the $\mathrm{CF}_{4}$ treated $\mathrm{ALD} \mathrm{TiO}_{2}$ are shifted toward more negative values $(-3.9$ and $-7.4 \mathrm{eV})$ with respect to the case of the reference $\mathrm{TiO}_{2}$ $(-3.8$ and $-7.15 \mathrm{eV})$. Combining the IP with the optical band gap of $3.4 \mathrm{eV}$ measured by spectroscopic ellipsometry, we conclude that the $\mathrm{CF}_{4}$ plasma treatment leads to a better alignment with the CB of the perovskite, when using the value of $3.9 \mathrm{eV},{ }^{[2]}$ which is generally reported in literature for the $\mathrm{MAPbI}_{3}$ (see Figure S5, Supporting Information). Our conclusion agrees with literature, where a deeper CB for the optimized ETL leads to highly efficient devices with respect to the one with unoptimized ETLs. ${ }^{[5,6]}$ At the same time, it is also reported that CB offsets in the range of $80-100 \mathrm{mV}$ do not hamper engineering of high-efficiency solar cells, and even an energy barrier of $100 \mathrm{mV}$ can lead to PCEs of $15 \%,,^{[5,6]}$ The contrasting results among literature data highlights that a deeper understanding and investigation of the interface electronic structure should be carried out. A valid example is few nanometer thick evaporated perovskite, which enabled a detailed analysis of the interface energy levels. ${ }^{[31,32]}$

To elucidate differences at the selective layer/perovskite interface, most authors refer to time-resolved photoluminescence (PL) measurements. Several papers point out that having a faster time-resolved PL decay indicates a faster charge extraction at the interface when investigating a semi cell (i.e., collector/ETL/perovskite). The time-resolved PL decay is generally fitted with a bi-exponential function providing two time constants, on the order of a few nanoseconds. While the faster time constant $\tau_{1}$ appears independent of the selective contact, the slower time constant $\tau_{2}$ is correlated to the charge extraction efficiency. ${ }^{[21,33-37]}$ Our PL measurements on the ETL/perovskite semi cells are reported in Figure S6 (Supporting Information) while the values of $\tau_{1}$ and $\tau_{2}$ calculated from the normalized PL measurements table are summarized in Table S3 (Supporting Information). We observe that the perovskite deposited on the fluorinated ALD $\mathrm{TiO}_{2}$ shows a faster PL decay with $\tau_{2}=5.3 \pm 0.2 \mathrm{~ns}$ compared to $8.1 \pm 0.5 \mathrm{~ns}$ in the case of the perovskite/ALD $\mathrm{TiO}_{2}$ sample. Therefore, we conclude that the fluorination of the ALD $\mathrm{TiO}_{2}$ leads to a superior interface in terms of electron charge extraction.

Furthermore, we also observe that literature often refers to improvement in binding/interfacial coupling/adhesion between $\mathrm{TiO}_{2}$ and the perovskite films..$^{[5,38,39]}$ In order to shed light on the large difference we observe in PCE values with and 

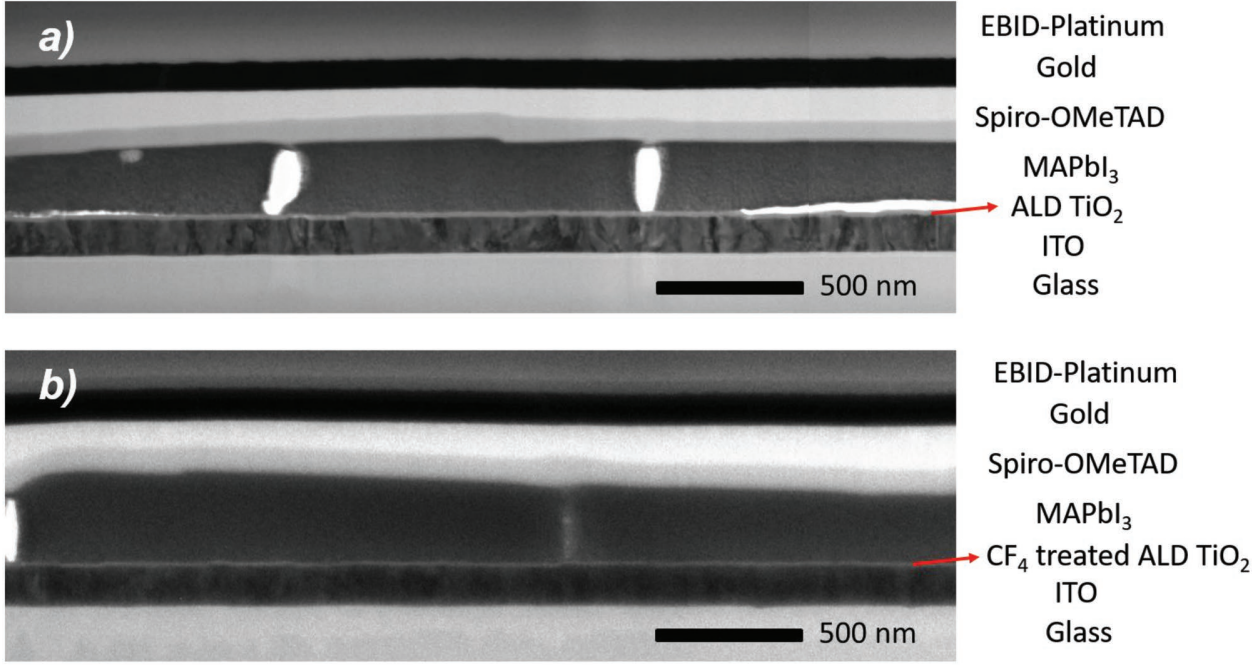

Figure 3. Bright field TEM images of the complete perovskite solar cells based on: a) $\mathrm{ALD} \mathrm{TiO}{ }_{2}$ layer and b) $\mathrm{CF}_{4}$ treated $\mathrm{ALD} \mathrm{TiO}_{2}$ layer.

without the $\mathrm{CF}_{4}$ plasma treatment, we investigate the transmission electron microscopy (TEM) cross section images of the two stacks. Figure 3a shows that for the reference sample, the $\mathrm{MAPbI}_{3}$ perovskite delaminates from the ALD $\mathrm{TiO}_{2}$ at two different locations (and at least four locations if we consider the complete TEM lamella reported in Figure S7, Supporting Information). While the amount of delamination at the $\mathrm{TiO}_{2} /$ perovskite interface might have been enhanced by the focus ion beam procedure to thin the lamella, no effects are detectable in the stack where the $\mathrm{CF}_{4}$ plasma treatment has been employed (Figure 3b). Therefore, the TEM image analysis suggests a weak ALD $\mathrm{TiO}_{2}$ /perovskite interface, prone to delamination, whereas the $\mathrm{CF}_{4}$ plasma treatment enables a more stable interface. The surface fluorination of the $\mathrm{TiO}_{2}$ seems to provide stronger chemical bonds with the perovskite. A similar explanation has been already proposed by Tan et al. ${ }^{[5]}$ where the chlorinated termination on the $\mathrm{TiO}_{2}$ surface enables the formation of $\mathrm{Pb}-\mathrm{Cl}$ bonds which suppress deep trap states near the valence band, decreasing the density of interfacial defects. ${ }^{[5]}$ Fluorine can chemically bond with $\mathrm{Pb}$ to form $\mathrm{Pb}-\mathrm{F}$ (i.e., $\mathrm{PbF}_{2}$ ). Due to the higher electronegativity of fluorine with respect to oxygen we suggest that $\mathrm{F}$ leads to stronger chemical bonds with the $\mathrm{Pb}$-terminated sites of the perovskite crystalline structure, in a similar way to chlorine. ${ }^{[5]}$ This explains why the fluorinated $\mathrm{TiO}_{2}$ /perovskite interface is more stable, it exhibits a faster electron extraction, and eventually leading to enhanced PV performance, as observed also in the other works using fluorinebased materials. ${ }^{[24-26]}$

In conclusion, we propose a simple and fast $\mathrm{CF}_{4}$ plasma treatment to modify the surface of the low-temperature ALD $\mathrm{TiO}_{2}$ layer. The F-rich surface appears crucial for a stronger adhesion at the interface with the $\mathrm{MAPbI}_{3}$ perovskite film leading to a PSC device with a stable efficiency of $14.8 \%$, significantly higher than the $4 \%$ obtained without the $\mathrm{CF}_{4}$ treatment. While the attention of this communication focuses on the $\mathrm{MAPbI}_{3}$, future investigations can explore whether combining the surface fluorination of the ALD $\mathrm{TiO}_{2}$ layer with other perovskite chemistries, i.e., mixed cation and anions, will lead to similar results.

\section{Experimental Section}

The ALD $\mathrm{TiO}_{2}$ layers were prepared in a plasma ALD reactor (Oxford Instruments FlexAL). After a predeposition oxygen plasma treatment $(200 \mathrm{~W})$ of $3 \mathrm{~min}, 444$ ALD cycles were performed to obtain a final thickness of $20 \mathrm{~nm}$. Here, a single ALD cycle consists of $8 \mathrm{~s}$ of $\mathrm{Ti}\left(\mathrm{OCH}\left(\mathrm{CH}_{3}\right)_{2}\right)_{4}$ (Sigma-Aldrich; commonly referred to as TTIP) precursor dosing, purging steps of $5 \mathrm{~s}$ with argon flow, $12 \mathrm{~s}$ of $\mathrm{O}_{2}$ plasma exposure $(100 \mathrm{~W})$, and a purging step of $3 \mathrm{~s}$ with argon flow. ${ }^{[40]}$ ALD depositions were carried out at $130^{\circ} \mathrm{C}$. Before the deposition of the perovskite, the layers underwent $\mathrm{UV}-\mathrm{O}_{3}$ treatment for $30 \mathrm{~min}$, and half of them were exposed to a $\mathrm{CF}_{4}$ plasma treatment $(400 \mathrm{~W})$ in a Barrel Plasma Etcher (Branson/IPC S2100-11220) for 1-5 min.

The $\mathrm{TiO}_{2}$ thickness and optical properties such as the band gap energy were obtained by fitting the ellipsometric data with an optical model based on a Tauc-Lorentz oscillator. The ellipsometric data were acquired using a J.A. Woollam, Inc., M2000U (1.2-6.5 eV) system.

The $\mathrm{MAPbl}_{3}$ perovskite layers were fabricated by spin-coating a precursor solution, of which the composition and annealing process were reported in the work of Qiu et al. ${ }^{[41]}$ SpiroOMeTAD solution was spincoated at $2000 \mathrm{rpm}\left(80 \mathrm{mg} \mathrm{mL}^{-1}\right.$ in chlorobenzene doped with $28.5 \mu \mathrm{L}$ tBP and $17.5 \mu \mathrm{L}$ of a $520 \mathrm{mg} \mathrm{mL}^{-1}$ solution of LitFSI in acetonitrile). The devices were terminated by thermally evaporating patterned gold electrodes (100 nm).

The perovskite devices were measured under a white-light halogen lamp source in combination with interference filters places in a nitrogen glove box, using a stainless steel mask $\left(0.09 \mathrm{~cm}^{2}\right)$. The light intensity was calibrated by a silicon reference cell. The $J-V$ curves were measured using a Keithley 2400 source at a scanning rate of $200 \mathrm{mV} \mathrm{s}$. The MPPT value refers to the output power monitored after short $(5 \mathrm{~min})$ or longer time $(14 \mathrm{~h})$.

The surface and bulk chemical compositions of the ALD $\mathrm{TiO}_{2}$ layers with and without $\mathrm{CF}_{4}$ plasma treatment were analyzed by XPS (Thermo Scientific K-Alpha KA1066, monochromatic Al K $\alpha(h v=1486.6 \mathrm{eV})$, X-ray spot: $400 \mu \mathrm{m})$. Ar+ gun was used to sputter the surface to analyze. All the spectra referred to $C 1 \mathrm{~s}$ peak at $284.6 \mathrm{eV}$.

For the band diagram at the $\mathrm{TiO}_{2}$ /perovskite interface, WFs and IP of the $\mathrm{TiO}_{2}$ films were characterized by UPS (VG EscaLab II system), using incident photons of $21.2 \mathrm{eV}(\mathrm{He} \mathrm{I})$ emitted by helium gas discharge as the light source. The WF was simply calculated by subtracting the value of the calculated secondary-electron cut-off from the energy of the ultraviolet excitation source $(21.22 \mathrm{eV})$. In a similar way, the IP is calculated by subtracting the difference between the WF value and the valence band edge from the energy of the ultraviolet excitation source. 
The edge energies were obtained by linearly extrapolating the tangents through the point of inflection of the edge to the background level.

XRD measurements have been carried out to evaluate the crystallinity of the samples (XRD; PanAlytical X'pert PRO MRD).

Cross-sectional TEM samples of the stacks were prepared using a standard focused ion beam liftout procedure. In the transfer step, the samples were mounted on molybdenum support grid and, then, the final thinning was performed. The subsequent TEM studies were performed using a JEOL ARM 200 probe corrected TEM, operated at $200 \mathrm{kV}$.

$\mathrm{PL}$ measurements were performed using excitation by a $635 \mathrm{~nm}$ pulsed laser (pulse width of $0.3 \mathrm{~ns}$ ) operating at $5 \mathrm{MHz}$, with an excitation intensity of $\approx 10^{12}$ photons $\mathrm{cm}^{-2}$ pulse $\mathrm{e}^{-1}$. The $\mathrm{PL}$ signal was passed through a diffraction grating to either an Si CCD detector (for spectral intensity measurements) or an avalanche photodiode connected to a PicoHarp 300 time-correlated single photon counting system (for time-resolved measurements). The latter were performed at a wavelength of $775 \mathrm{~nm}$.

\section{Supporting Information}

Supporting Information is available from the Wiley Online Library or from the author.

\section{Acknowledgements}

The authors acknowledge the Dutch Ministry of Economic Affairs, via The Top-consortia Knowledge and Innovation (TKI) Program "High Efficiency Hybrid Tandem Solar Cells" (TEZ0214010) and HIPER (TEUE116193). The TEM analysis has been supported also by Solliance, a partnership of R\&D organizations from The Netherlands, Belgium, and Germany working in thin film photovoltaic solar energy. The authors acknowledge professor Koenraad and professor Bakkers at the Applied Physics department (TU/e) for the access to the PL facility.

\section{Conflict of Interest}

The authors declare no conflict of interest.

\section{Keywords}

$\mathrm{CF}_{4}$ plasma, low-temperature atomic layer deposition, perovskite, surface treatment, $\mathrm{TiO}_{2}$

Received: November 8, 2017 Revised: January 31, 2018 Published online: March 14, 2018

[1] W. S. Yang, B.-W. Park, E. H. Jung, N. J. Jeon, Y. C. Kim, D. U. Lee, S. S. Shin, J. Seo, E. K. Kim, J. H. Noh, S. II Seok, Science 2017, 356, 1376.

[2] P. Gao, M. Grätzel, M. K. Nazeeruddin, Energy Environ. Sci. 2014, 7, 2448 .

[3] T. K. Todorov, D. M. Bishop, Y. S. Lee, Sol. Energy Mater. Sol. Cells 2017, http://dx.doi.org/10.1016/j.solmat.2017.07.033.

[4] D. Bi, C. Yi, J. Luo, J.-D. Décoppet, F. Zhang, S. M. Zakeeruddin, X. Li, A. Hagfeldt, M. Grätzel, Nat. Energy 2016, 1, 16142.

[5] H. Tan, A. Jain, O. Voznyy, X. Lan, F. P. G. de Arquer, J. Z. Fan, R. Quintero-Bermudez, M. Yuan, B. Zhang, Y. Zhao, F. Fan, P. Li,
L. N. Quan, Y. Zhao, Z.-H. Lu, Z. Yang, S. Hoogland, E. H. Sargent, Science 2017, 355, 722.

[6] J. P. Correa Baena, L. Steier, W. Tress, M. Saliba, S. Neutzner, T. Matsui, F. Giordano, T. J. Jacobsson, A. R. Srimath Kandada, S. M. Zakeeruddin, A. Petrozza, A. Abate, M. K. Nazeeruddin, M. Grätzel, A. Hagfeldt, Energy Environ. Sci. 2015, 8, 2928.

[7] F. Di Giacomo, A. Fakharuddin, R. Jose, T. M. Brown, Energy Environ. Sci. 2016, 9, 3007

[8] E. H. Anaraki, A. Kermanpur, L. Steier, K. Domanski, T. Matsui, W. Tress, M. Saliba, A. Abate, M. Grätzel, A. Hagfeldt, J.-P. CorreaBaena, Energy Environ. Sci. 2016, 9, 3128.

[9] S. S. Mali, A. I. Inamdar, H. Im, S. E. Shim, C. K. Hong, Nanoscale 2017, 9, 3095.

[10] F. Di Giacomo, V. Zardetto, G. Lucarelli, L. Cinà, A. Di Carlo, M. Creatore, T. M. Brown, Nano Energy 2016, 30, 460.

[11] X. Dong, H. Hu, B. Lin, J. Ding, N. Yuan, Chem. Commun. 2014, 50, 14405 .

[12] F. Di Giacomo, V. Zardetto, A. D'Epifanio, S. Pescetelli, F. Matteocci, S. Razza, A. Di Carlo, S. Licoccia, W. M. M. Kessels, M. Creatore, T. M. Brown, Adv. Energy Mater. 2015, 5, 1401808.

[13] D. Wang, M. Wright, N. K. Elumalai, A. Uddin, Sol. Energy Mater. Sol. Cells 2016, 147, 255

[14] B.-J. Kim, D. H. Kim, Y.-Y. Lee, H.-W. Shin, G. S. Han, J. S. Hong, K. Mahmood, T. Ahn, Y.-C. Joo, K. S. Hong, N.-G. Park, S. Lee, H. S. Jung, Energy Environ. Sci. 2015, 8, 916.

[15] V. Zardetto, F. Di Giacomo, G. Lucarelli, W. M. M. Kessels, T. M. Brown, M. Creatore, Sol. Energy 2017, 150, 447.

[16] J. A. van Delft, D. Garcia-Alonso, W. M. M. Kessels, Semicond. Sci. Technol. 2012, 27, 74002 .

[17] S. M. George, Chem. Rev. 2010, 110, 111.

[18] H. B. Profijt, S. E. Potts, M. C. M. van de Sanden, W. M. M. Kessels, J. Vac. Sci. Technol., A 2011, 29, 50801.

[19] P. Poodt, D. C. Cameron, E. Dickey, S. M. George, V. Kuznetsov, G. N. Parsons, F. Roozeboom, G. Sundaram, A. Vermeer, J. Vac. Sci. Technol., A 2012, 30, 10802.

[20] V. Zardetto, B. L. Williams, A. Perrotta, F. Di Giacomo, M. A. Verheijen, R. Andriessen, W. M. M. Kessels, M. Creatore, Sustainable Energy Fuels 2017, 1, 30.

[21] A. E. Shalan, S. Narra, T. Oshikiri, K. Ueno, X. Shi, H.-P. Wu, M. M. Elshanawany, E. W.-G. Diau, H. Misawa, Sustainable Energy Fuels 2017, 1, 1533.

[22] Y. Wu, X. Yang, H. Chen, K. Zhang, C. Qin, J. Liu, W. Peng, A. Islam, E. Bi, F. Ye, M. Yin, P. Zhang, L. Han, Appl. Phys. Express 2014, 7, 52301.

[23] G. Lucarelli, F. Di Giacomo, V. Zardetto, M. Creatore, T. M. Brown, Nano Res. 2017, 1, 1

[24] M. Salado, M. A. Fernández, J. P. Holgado, S. Kazim, M. K. Nazeeruddin, P. J. Dyson, S. Ahmad, ChemSusChem 2017, 10, 3846.

[25] J.-H. Yu, C.-H. Lee, H.-I. Joh, J.-S. Yeo, S.-I. Na, Nanoscale 2017, 9, 17167.

[26] K. Liu, S. Dai, F. Meng, J. Shi, Y. Li, J. Wu, Q. Meng, X. Zha, J. Mater. Chem. A 2017, 5, 21414.

[27] S. Norasetthekul, P. Y. Park, K. H. Baik, K. P. Lee, J. H. Shin, B. S. Jeong, V. Shishodia, E. S. Lambers, D. P. Norton, S. J. Pearton, Appl. Surf. Sci. 2001, 185, 27.

[28] S. Wang, X. Liu, L. Wang, Q. Wen, N. Du, J. Huang, RSC Adv. 2017, 7, 16078.

[29] J.-Y. Ruzicka, F. A. Bakar, L. Thomsen, B. C. Cowie, C. McNicoll, T. Kemmitt, H. E. A. Brand, B. Ingham, G. G. Andersson, V. B. Golovko, RSC Adv. 2014, 4, 20649.

[30] T.-C. Tien, F.-M. Pan, L.-P. Wang, C.-H. Lee, Y.-L. Tung, S.-Y. Tsai, C. Lin, F.-Y. Tsai, S.-J. Chen, Nanotechnology 2009, 20, 305201.

[31] S. Olthof, K. Meerholz, Sci. Rep. 2017, 7, 1.

[32] T. Hu, T. Becker, N. Pourdavoud, J. Zhao, K. O. Brinkmann, R. Heiderhoff, T. Gahlmann, Z. Huang, S. Olthof, K. Meerholz, 
D. Többens, B. Cheng, Y. Chen, T. Riedl, Adv. Mater. 2017, 29, 1606656.

[33] W. Yu, F. Li, H. Wang, E. Alarousu, Y. Chen, B. Lin, L. Wang, M. N. Hedhili, Y. Li, K. Wu, X. Wang, O. F. Mohammed, T. T. Wu, Nanoscale 2016, 8, 6173.

[34] W. Chen, Y. Wu, Y. Yue, J. Liu, W. Zhang, X. Yang, H. Chen, E. Bi, I. Ashraful, M. Grätzel, L. Han, M. Gratzel, L. Han, Science 2015 , 350, 944.

[35] B.-X. Chen, H.-S. Rao, W.-G. Li, Y.-F. Xu, H.-Y. Chen, D.-B. Kuang, C. Su, J. Mater. Chem. A 2016, 4, 5647.

[36] W. Sun, Y. Li, S. Ye, H. Rao, W. Yan, H. Peng, Y. Li, Z. Liu, S. Wang, Z. Chen, L. Xiao, Z. Bian, C. Huang, Nanoscale 2016, 8, 10806.
[37] X. Yao, J. Liang, Y. Li, J. Luo, B. Shi, C. Wei, D. Zhang, B. Li, Y. Ding, Y. Zhao, X. Zhang, Adv. Sci. 2017, 4, 1700008.

[38] E. Mosconi, E. Ronca, F. De Angelis, J. Phys. Chem. Lett. 2014, 15, 2619.

[39] L. Cojocaru, S. Uchida, Y. Sanehira, J. Nakazaki, T. Kubo, H. Segawa, Chem. Lett. 2015, 44, 674

[40] S. E. Potts, W. Keuning, E. Langereis, G. Dingemans, M. C. M. van de Sanden, W. M. M. Kessels, J. Electrochem. Soc. 2010, 157, P66.

[41] W. Qiu, T. Merckx, M. Jaysankar, C. Masse de la Huerta, L. Rakocevic, W. Zhang, U. W. Paetzold, R. Gehlhaar, L. Froyen, J. Poortmans, D. Cheyns, H. J. Snaith, P. Heremans, Energy Environ. Sci. 2016, 9, 484. 